\title{
The Role of Internal Audit in Good Corporate Governance Implementation at Politeknik Negeri Batam
}

\author{
Gita Anadia Maulina* and Dwi Kartikasari * \\ *Politeknik Negeri Batam \\ Business Administration Study Program \\ Jl A Yani, Batam Kota, Batam 29461, Indonesia \\ E-mail: dwi@polibatam.ac.id
}

\begin{abstract}
Abstrak
Politeknik Negeri Batam adalah satu-satunya Perguruan Tinggi Negeri Vokasi di daerah perdagangan bebas Batam, Bintan, dan Karimun di Provinsi Kepulauan Riau, yang harus menerapkan Good Corporate Governance mengikuti mengikuti prinsip dan pedoman yang ditetapkan oleh Komite Nasional Kebijakan Governance (KNKG). Audit internal adalah salah satu elemen dalam Good Corporate Governance dan memiliki peran dalam mengawasi implementasi manajemen dan mengawasi praktik apa pun yang dilakukan oleh institusi. Penerapan Good Corporate Governance di Politeknik Negeri Batam harus mengikuti mengikuti pedoman Good Corporate Governance oleh KNKG. Oleh karena itu, penelitian ini bertujuan untuk menjelaskan implementasi Good Corporate Governance di Politeknik Negeri Batam dan untuk mengetahui peran audit internal untuk mewujudkan implementasi prinsip-prinsip Good Corporate Governance. Jenis penelitian ini adalah deskriptif kualitatif yang mana data dikumpulkan dari hasil observasi, wawancara, dan dokumentasi. Hasil dari penelitian ini adalah Politeknik Negeri Batam telah menerapkan Good Corporate Governance sesuai dengan aturan yang berlaku. Selanjutnya, audit internal berperan dalam mewujudkan implementasi Good Corporate Governance di Politeknik Negeri Batam.
\end{abstract}

Kata kunci: audit internal, good corporate governance, komite nasional kebijakan governance, peran

\begin{abstract}
Politeknik Negeri Batam is the only vocational government-owned higher education in the free trade area of Batam, Bintan, and Karimun, in the province of Riau Islands, which must implement Good Corporate Governance in accordance with the established principles and guidelines set by National Committee on Governance Policy (KNKG). Internal audit is one of the elements in Good Corporate Governance and has a role in overseeing management implementation and any practice carried out by the institution. Therefore, this study aims to describe the implementation of Good Corporate Governance in Politeknik Negeri Batam and to know the role of internal audit in realizing the Good Corporate Governance. The analytical method used in this research is descriptive qualitative method with data collected from observation, interviews and documentation. The results of this study is Politeknik Negeri Batam has implemented Good Corporate Governance according to applicable rules. Furthermore, internal audits play an important role in realizing the Good Corporate Governance of Politeknik Negeri Batam.
\end{abstract}

Keywords: internal audit, good corporate governance, KNKG, role

\section{Introduction}

Every institution has a goal to achieve effectiveness and efficiency in its management system. Especially a state higher education institution given it obtained the fundings from the central government, so that it will be acoounted for the responsibility directly to the ministry of education. Therefore, Good Corporate Governance (GCG) is needed in every management of institution that is owned by the government.
Good Corporate Governance can be used as one of the keys to the success of an institution in managing good organization and government. Basically, the implementation of GCG is carried out not only in the private sector but also in the government sector. If an institution either the government or the private sector implements GCG to the fullest, it can assist the institution in achieving the goals and objectives. In an effort to apply the principles of Good Corporate Governance, the role of the institution's internal audit 
will be very important [1].

Generally, conducting an internal audit can help an institution to achieve its goals and objectives. Through a regular and systematic approach, the function of the institution's internal audit itself is to improve the effectiveness of controls from the risk management process, evaluating, and institutional management. Internal audit hold examinations that will be carried out by internal institutions, on accounting records and institutional financial reports and on policies that have been determined by the government such as regulations in the capital market, taxation, investment, environment, industry, etc. [2]

The internal audit unit conducts audits directly within the institution. Authority and responsibility in carrying out internal audits is provided by management to supervise and assess internal institutional controls. Basically, internal audits are carried out to improve business efficiency in institutions, encourage compliance with management policies that have been made to protect the assets of the institution and assess the accuracy of accounting data. Now, there are many internal audits that provide services for checking and assessing risk [3], performance, control and governance for institutions engaged in education [4].

Implementing a system of GCG within an institution is a pillar for the realization of a healthy institution. The internal audit system mechanism within the institution is a cornerstone to be able to ensure that the management carried out by the institution effectively based on the rules of GCG. The era of globalization has made changes that occur in an ever-changing educational environment demanding the development of a new paradigm and system in carrying out institutional operations. Errors in the application of the system of GCG within the institution caused an economic crisis that had occurred in the Asia and Latin America regions [5]. Seeing cheating that happened well in the international business world made domestic practitioners aware that there was a need to prevent fraud in institutions.

GCG emerges as an option that is not merely a matter of formality, but a very fundamental value system and best practices carried out by institutions to enhance institutional value especially for the state higher education institution [4]. And lately, GCG has become an absolute thing that should be owned by an institution. Thus, to realize the implementation of good GCG, the role of certain parties is urgently needed, especially the role of direct internal audit of the institution. Because in monitoring and evaluating the operational activities of the institution, internal audit is also responsible by ensuring that the institution has carried out its operational activities in accordance with the application of the principles of GCG which include: transparency, accountability, responsibility, independency and fairness [6][7].
Politeknik Negeri Batam is the only vocational government-owned higher education in the free trade area of Batam, Bintan, and Karimun, in the province of Riau Islands, which must implement GCG [8] in accordance with the established principles and guidelines set by National Committee on Governance Policy (KNKG) [6]. Internal audit is one of the elements in GCG and has a role in overseeing management implementation and any practice carried out by the institution. Therefore, this study aims to describe the implementation of GCG in Politeknik Negeri Batam and to know the role of internal audit in realizing the GCG. This paper attempts to enrich literature by giving more cases to the implementation of GCG in universities, either public [9] or private [10], but especially this paper extends the literature on vocational higher education.

\section{Literature Review}

In general, internal audit activities carried out by both government and private institutions are to assist management members in completing their duties and responsibilities effectively, by providing results of analysis, comments and suggestions objectively as well as evaluating the activities that have been carried out [11]. Internal audit serves to provide various kinds of assistance to institutions including employee performance audits and institutional operational audits that can help the board of commissioners and senior management in monitoring activities carried out by management and members within the institution so that internal auditors can provide assessments independent of how well the organization is performing [12].

GCG is as a system to regulate the relationship of the role of the Board of Directors, the role of the Board of Commissioners, shareholders and other stakeholders [2]. A transparent process for determining assessment of performance, achievement and objectives of the institution is also called GCG. The principles of GCG compiled by the KNKG [6] include:

1. Transparency of the information must be done so that all employees involved in it can clearly understand the state of the institution so that the assessment of universities will increase.

2. Accountability is the clarity of functions, structural accountability so that the institution can run effectively and efficiently.

3. Independency is an institution's capability of acting professionally in accordance with its roles and functions without conflict of interest and also without pressure or intervention from the parties or those that do not comply with the laws set by the government.

4. Responsibility is that every institution, both government and private, must follow every 
applicable regulation, including the relationship between institutions and the community, tax issues, occupational safety and health, and so forth.

5. Fairness is when an institution able to provide opportunities to employees and all those involved in it fairly and professionally based on the principle of transparency in the position of each and the scope of the institutional structure.

\section{Research Method}

This research method uses a qualitative descriptive method. Descriptive qualitative is a research method that is based on postpositivism philosophy, and is used to examine the conditions of natural objects, where researchers are key, and techniques for collecting data by comparing data differently, analysis of data is inductive or qualitative, and the results of qualitative research will prioritize an explanation rather than generalization [13]. The subjects of this study are three interviewees who serve in the department of internal audit in Politeknik Negeri Batam with minimum 4 years of experience in auditing, nationally ISO certified and accountant certified. Interview data are supported by observation during interview and documentation as evidence. Instrument is adapted from previous study [14] where each variable operationalized in table 1 below.

TABLE I

OPERATIONALIZATION OF VARIABLES

\begin{tabular}{|c|c|c|}
\hline Variable & Dimension & Indicator \\
\hline \multirow[t]{5}{*}{$\begin{array}{c}\text { Good } \\
\text { Corporate } \\
\text { Governance } \\
\text { (GCG) }\end{array}$} & Transparency & $\begin{array}{l}\text { - On time, sufficient, clear, } \\
\text { accurate, comparable } \\
\text { information } \\
\text { - Scope of information } \\
\text { provided: vision, mission, } \\
\text { strategy, financial } \\
\text { transparency } \\
\text { - Confidentiality agreement } \\
\text { - Written policy }\end{array}$ \\
\hline & Accountability & 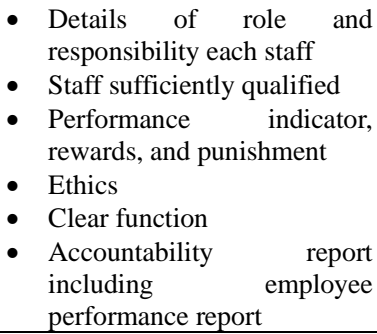 \\
\hline & Independency & $\begin{array}{l}\text { - } \\
\text { - Prominance in institution } \\
\text { - Staff work as stated function } \\
\text { and job desc }\end{array}$ \\
\hline & Responsibility & 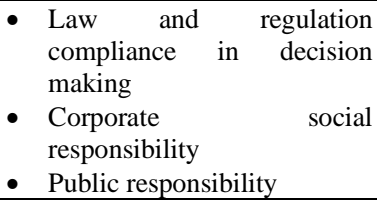 \\
\hline & Fairness & $\begin{array}{ll}\text { - } & \text { Institution fairness } \\
\text { - Stakeholders access and } \\
\text { voice to information }\end{array}$ \\
\hline
\end{tabular}

\begin{tabular}{|c|c|c|}
\hline Variable & Dimension & Indicator \\
\hline & & $\begin{array}{l}\text { - } \begin{array}{l}\text { Stakeholder's rights } \\
\text { proportional to her } \\
\text { contribution }\end{array} \\
\text { - } \begin{array}{l}\text { Fair opportunity to advance } \\
\text { career }\end{array}\end{array}$ \\
\hline \multirow[t]{6}{*}{$\begin{array}{c}\text { Audit } \\
\text { Internal }\end{array}$} & Independence & - Separate from other function \\
\hline & $\begin{array}{l}\text { Professional } \\
\text { Ability }\end{array}$ & $\begin{array}{ll}\text { - } & \begin{array}{l}\text { Education and experience } \\
\text { requirement }\end{array} \\
\text { - } & \begin{array}{l}\text { Proportional role and } \\
\text { responsibility }\end{array}\end{array}$ \\
\hline & Objective & $\begin{array}{ll}- & \text { Target unit } \\
- & \text { Coordination } \\
& \text { communication }\end{array}$ \\
\hline & Competence & - Training \\
\hline & Scope of Work & $\begin{array}{l}\text { - Scope of work including } \\
\text { policy and procedure audit }\end{array}$ \\
\hline & $\begin{array}{c}\text { Management } \\
\text { of the Internal } \\
\text { Auditor } \\
\text { Department }\end{array}$ & $\begin{array}{l}\text { - } \\
\text { - } \\
\text { Discussion } \\
\text { management } \\
\text { - } \begin{array}{l}\text { Direction } \\
\text { recommendation for the } \\
\text { management }\end{array}\end{array}$ \\
\hline
\end{tabular}

\section{Results and Discussions}

\section{Transparency}

The implementation of the principle of transparency in Politeknik Negeri Batam has been running as a whole. All forms of information that are comprehensive for all academic institutions are well implemented. However, there were also activities in the implementation of transparency that were not carried out by Politeknik Negeri Batam. One of them is that information about financial statements is known limitedly by some departments only. Because Politeknik Negeri Batam is a government-owned institution that is not listed on the stock exchange so that the institution's financial statements are not obliged to fully disclosure to the public.

This is different from one of the previous studies in a Bank regarding financial statements which was quite transparent due to a meeting where all employees gathered regularly a couple of times within a year and would jointly discuss the company's condition and financial condition [15]. In this regard, it might be a good idea to hold a more regular meeting in Politeknik Negeri Batam to discuss not only financial disbursement but also key performance indicator that has been achieved as a result of this disbursement. Transparency is among the weakest indicator of GCG in previous study in a university [10] and in ceramic industry [14].

\section{Accountability}

The implementation of the accountability principle has been fully carried out by the Batam State Polytechnic as assured by internal audit department. This is proven by the fact that employees have qualifications that are in accordance with the duties, roles and responsibilities based on the standards and operating procedure (SOP)

3 | Jurnal Akuntansi, Ekonomi dan Manajemen Bisnis | Vol. 9 No.1, July 2021, 1-6 | E-ISSN: 2548-9836 
in each unit or division so that the division of tasks and responsibilities carried out will also be adjusted to the capability and competence of the employees themselves.

This finding is a little different from previous research [15] where the principle of accountability worked quite well, however there was lack of commitment and consistency from employees in carrying out their responsibilities. Besides transparency issues, accountability is quite often found as the weak link the chain of GCG. This risk may be anticipated by consistent training and regular organization's value and vision socialization. Top management is not found to corrupt and not underperform which is good and commonly found in other studies [10], [14].

\section{Responsibility}

The implementation of the principle of responsibility has been carried out as a whole very well in Politeknik Negeri Batam. This is evidenced when decision making regarding the financial statements is very carefully ensured to comply with laws and regulations. Everything must be backed up with evidence before it is submitted to the management. The strong compliance attitude towards laws and regulations is unsurprising given this institution is part of the goverment.

Politeknik Negeri Batam also carried out social responsibility, namely working with Pertamina by conducting family welfare empowerment to housewives in Nongsa. In this case, this research and previous research are not much different because the principle of responsibility has been carried out as a whole [15].

\section{Independency}

The implementation of the principle of independence in Politeknik Negeri Batam has been running as a whole. Domination of one person or one party in institutional organs is greatly avoided so that employees make decision independently considering sets of criteria and procedures, not depending on preference of one dominant person. One of the things that is done in implementing independence is making the banner rejecting bribery or gratification. In this case, this research complies with previous research at Bank BTN [15] because the principle of independence has been implemented well where employees have their respective duties and functions and decision-making is not depending on the dominance of any party.

\section{Fairness}

The implementation of the principle of fairness is only done partly because the most important thing in the principle of fairness in Politeknik Negeri Batam is fairness in using the country's accounting standards in each financial report. Because Politeknik Negeri Batam is a government-owned institution that does not have shareholders in it, the role of shareholders to describe input and opinions and access to information on these institutions is limited. In this case, the intended stakeholders are the senate of Politeknik Negeri Batam. This finding differs from previous research [15] where Bank BTN has shareholders who can give opinions and input to the organization. As a university, Politeknik Negeri Batam is not comparable to private organization. Furthermore, good university governance (GUG) is arguably not standardized in practice, although holding the same principles [9].

In other universities, boards of trustees (Majelis Wali Amanat) holds the top level stakeholders representing government, society and internal party. This body does not exist in Politeknik Negeri Batam according to its statute, which subject to reconsideration in the future. This body is expected to increase the function of supervision to top management that will result in economical, efficient, and effective (3E) management [9].

\section{Good Corporate Governance Implementation}

Overall, Politeknik Negeri Batam has implemented the principles of GCG properly. This makes Politeknik Negeri Batam a university with very good quality because both staff and lecturers have the qualifications of duties and responsibilities that are in accordance with their respective fields. This is also evidenced by a review of the results of the audit conducted by internal audits who work independently and avoid domination must always follow the laws and regulations. In this case, in Politeknik Negeri Batam is very supportive in the career development of its employees. However, there are still some shortcomings in its implementation, especially in the transparency of financial statements that cannot be informed to everyone because Politeknik Negeri Batam is a government state institution where it is only responsible later to the government or the ministry.

\section{The Role of Internal Audit in Realizing the Implementation of Good Corporate Governance}

The reason for the internal audit to implement GCG is that activities related to governance can run transparently, effectively and efficiently. This reason is supported by numerous studies [9], [15] that internal audit serves as a companion to external audits who works transparently in providing documents and data needed by external auditors.

Internal audit must also know the relationship between internal audit and GCG so that implementation will become meaningful and accountable. Past study shows [15] that the internal audit must also have the duty to examine asset management in an accountable and prudent manner so that it can be accountable to all 
stakeholders.

Internal audit as a companion in carrying out GCG has responsibility only to the Director. Independent internal audits that are separate from other units so that they do not take sides in realizing GCG that is operationally good. It is also not much different from previous research [9], [15] that internal audit has direct responsibility to the President Director in accordance with the position of internal audit directly under the President Director so that in carrying out his duties there is no interference from other units and shareholders.

Internal audit conduct audits based on applicable regulations in order to achieve GCG. The audits that will be carried are out mainly on audit of financial statements, compliance audit, performance audit, operational audit, audit of specific objectives if needed and other audits. Of course the audit that carried out must be based on evidence and are based on regulations such as financial statements that must comply with the accounting standards. In the previous study, internal audits were conducted periodically from its headquarters.

The internal audit process in realizing GCG is also based on SOP and legislation. Which before the audit starts, the head of internal audit will form a team that is adjusted to the object to be audited. After the formation of a team, work programs are made into working papers. An audit work paper will be made a report that will later be submitted to management. In this case, the role of internal audit in realizing GCG is in line with previous research [15] where internal audits carry out their duties independently without being bound by any party in accordance with procedures so that GCG can be realized properly.

The role of internal audit as a companion to other units is sufficiently carried out as a whole in realizing the implementation of GCG ini Politenik Negeri Batam. The position of internal audit is only directly responsible to the Director and independent so that the internal audit can carry out its duties without being bound by other units effectively and efficiently. In realizing GCG, internal audit always follows the laws and regulations in carrying out its duties both financial report audits, operational audits, compliance audits, performance audits and other types of audits. Internal audit as a companion to other units also performs their duties according to the direction of the ministry so that the results of the audit report will be submitted directly to the Director before later to the ministry.

\section{Practical Implications}

Obviously Batam State Polytechnic has carried out GCG well. This research practically calls for it maintaining what has been done and improving the quality of internal audit. As found in this study, transparency and accountability are the weak link in GCG implementation. Thus, the institution should consistently pay attention on keeping communication of vision, mission, values, and strategies clear and straightforward to minimize the risk of prejudice and misscommunication. This is not the responsibility of internal audit alone, but also top management supported by all other units so that the objectives of implementing GCG can be achieved. More socializing about GCG to each unit and the objectives to be carried out by institutions is also needed to improve the quality of GCG.

\section{Limitations}

This research only focuses on the results of interviews with interviewees at the internal audit department or SPI Batam State Polytechnic. Therefore, this research is subjective and not transferrable to other settings. This limitation is a result of the point we discussed earlier that the implementation of GCG is practically different from one organization to another.

\section{Conclusions}

Overall, Politeknik Negeri Batam has implemented the principles of GCG properly. This fact is evidenced by the review of the results of the audit conducted by an internal audit carried out independently where regulation must always be taken into account. All employees also have the qualifications to carry out their duties and responsibilities according to the SOP of each unit. However, there are still some shortcomings in its implementation, most of which involve financial reporting that cannot be informed to literally everyone or made public due to Politeknik Negeri Batam is the government-owned institution.

The role of internal audit as a companion to other units is sufficiently implemented as a whole in realizing the implementation of Good Corporate Governance in Politeknik Negeri Batam. The position of internal audit is only directly responsible to the Director and independent so that the internal audit can carry out its duties without being bound by other units effectively and efficiently. Internal audit works based on laws and regulations for each type of audit, both financial statement audits, operational audits, compliance audits, performance audits and other types of audits.

\section{References}

A. J. Zou, "On the Role of Internal Audit in Corporate Governance," Am. J. Ind. Bus. Manag., vol. 09, no. 01, pp. 63-71, Jan. 2019, doi: 10.4236/ajibm.2019.91005.

B. S. Agoes, "Auditing: Petunjuk praktis pemeriksaan akuntan oleh akuntan publik." Jakarta: Salemba 
Empat, 2012.

C. D. Kartikasari, "Perancangan Prosedur Berbasis Manajemen Risiko pada Perguruan Tinggi dalam Rangka Migrasi ke ISO 9001: 2015," J. Appl. Account. Tax., vol. 3, no. 2, pp. 143-149, 2018.

D. G. Eke, "Internal Audit and Corporate Governance Effectiveness in Universities in Rivers State," Eur. J. Accounting, Audit. Financ. Res., vol. 6, no. 4, pp. 35-58, 2018, [Online]. Available: www.eajournals.org.

E. M. A. Daniri, “Good corporate governance: Konsep dan Penerapannya Dalam Konteks Indonesia, Edisi Kedua,” Jakarta PT Ray Indones., 2006.

F. Komite Nasional Kebijakan Governance, Pedoman Umum Good Corporate Governance Indonesia. Jakarta, 2006.

G. M. Mahipal, "To Know the Guidance of Good Corporate Governance in Indonesia (Indonesian)," SSRN Electron. J., Aug. 2010, doi: 10.2139/ssrn.1679131.

H. D. Kartikasari, M. Ansori, R. Irawati, and D. Mulyaningtyas, "Cost-Benefit Analysis on ISO 9001 Certification and Higher Education Accreditation," J. Cakrawala Pendidik., vol. 37, no. 3, pp. 470-481, 2018.

I. S. Sukirman and M. P. Sari, "Peran Internal Audit Dalam Upaya Mewujudkan Good University Governance Di Unnes," J. Din. Akunt., vol. 4, no. 1, pp. 64-71, 2012, [Online]. Available: https://journal.unnes.ac.id/nju/index.php/jda/article /view/1961/2079.

J. L. D. Iryani and S. Arsanti, "Efektivitas Internal Audit Dan Pelaksanaan Good University Governance Pada Perguruan Tinggi," JIMFE (Jurnal Ilm. Manaj. Fak. Ekon., vol. 5, no. 1, pp. 54-60, 2013, doi: 10.34203/jimfe.v5i1.717.

K. Hery, Potret Profesi Audit Internal. Bandung: Alfabeta, 2010.

L. A. Kurniawan, Audit Internal: Nilai Tambah Bagi Organisasi. BPFE Yogyakarta, 2012.

M. Sugiyono, Metode penelitian pendidikan:(pendekatan kuantitatif, kualitatif dan $R \& D)$. Alfabeta, 2008.

N. F. Widjaja and R. H. Mustamu, "Pengaruh Sistem
Pengendalian Internal Terhadap Implementasi Prinsip-Prinsip Good Corporate Governance Pada Perusahaan Industri Keramik," Agora, vol. 2, no. 1, pp. 1-9, 2014.

O. L. Oroh, Ayu Anita Ekaristi Kalangi and A. Wangkar, “Analisis Peranan Audit Internal dalam Mewujudkan Pelaksanaan Good Corporate Governance pada PT Bank Tabungan Negara, Tbk Manado," J. Ris. Akunt. Going Concern, vol. 13, no. 3, pp. 19-33, 2018.

6 | Jurnal Akuntansi, Ekonomi dan Manajemen Bisnis | Vol. 9 No.1, July 2021, 1-6 | E-ISSN: 2548-9836 